\section{Superior lines candidates evaluation of two local red rice Southeast Sulawesi cultivars (Indonesia) derived from gamma rays irradiation techniques}

\author{
Ni Wayan Sri Suliartini, ${ }^{1}$ Kuswanto, ${ }^{2}$ \\ Nur Basuki, ${ }^{2}$ Andy Soegianto ${ }^{2}$ \\ ${ }^{1}$ Faculty of Agriculture, Halu Oleo \\ University, Kendari, Southeast Sulawesi; \\ ${ }^{2}$ Faculty of Agriculture, Brawijaya \\ University, East Java, Indonesia
}

\begin{abstract}
The aim of this research was to describe the potency of superior cultivar upland rice candidates (gogo rice) first generation (M1) which generated from Pae Pulu Pongasi and Pae Loilo, Southeast Sulawesi, Indonesia. The grains were irradiated by 60 Co gamma-rays at 100, 200, 300, and $400 \mathrm{~Gy}$ doses. The developed cultivar was selected from numerous red and black rice with highest anthocyanins. Based on $\mathrm{LD}_{50}$ test to these cultivars, Pae Pulu Pongasi cultivar was founded at 416 Gy and Pae Loilo about 360 Gy. Ten superior lines candidates were selected, namely M1.27K2D1, M1.190K2D3 which are derived from M1 Pae Pulu Pongasi cultivar and M1.6K3D1, M1.24K3D1， M1.37K3D1， M1.102K3D1, M1.104K3D1, M1.162K3D1, M1.170K3D1 which derived from M1 Pae Loilo cultivars. M1.81K2D1 derived from M1 Pae Pulu Pongasi had the potential to produce higher yield, high lodging resistance, and short harvest age compared to parental.
\end{abstract}

\section{Introduction}

Red rice is one of the important functional foods with highest anthocyanins and antioxidant content in its grains. The test of anthocyanins content was implemented to 13 local paddy cultivars from 4 regencies in Indonesia, Southeast Sulawesi, namely South Konawe, Buton, North Buton and Muna. Previous research showed that the variety of anthocyanins content of upland red rice cultivar from Southeast Sulawesi was considered high. The highest anthocyanins content was founded on Pae Pulu Pongasi and Pae Loilo cultivars. ${ }^{1}$

The genetic improvement was needed in order to measure the genetic erosion of upland red rice in Southeast Sulawesi. Genetic improvements can be carried out through mutation induction. Mutation induction aims to increase the genetic diversity of numerous local upland red rice cultivars as basis material for selection and change bad character without altering good characters. Previous research showed that New Barley cultivar Centenario has grain productivity about $5.552 \mathrm{~kg} . \mathrm{ha}^{-1}$ and shorter harvest age (141 days) through gamma rays induction of $300 \mathrm{~Gy}{ }^{2}$ The research showed that mutation induction effective to produce a plant with shorter harvest age and higher productivity. The aim of this research was to describe the potency of superior cultivar candidates of upland rice (gogo rice) first generation (M1) which generated from two local upland red rice cultivar from Southeast Sulawesi.

\section{Materials and Methods}

In order to test $\mathrm{LD}_{50}$, the seeds of upland rice cultivar Pae Pulu Pongasi and Pae Loilo (11.8\% water content) were irradiated using $60 \mathrm{Co}$ gamma rays. There were $100 \mathrm{~Gy}, 200 \mathrm{~Gy}, 300$ Gy, $400 \mathrm{~Gy}$, and $500 \mathrm{~Gy}$ dosages treatment used for Paebiu Had and 100 Gy, 200 Gy, 300 Gy, 400 Gy dosages to Pae Loilo. About 500 grains were used and tested in every dosage. The $\mathrm{LD}_{50}$ was measured on the plants which able grows at 14 days after planting.

In order to evaluate the characters diversity of upland rice, gamma rays irradiation treatment was implemented. The dosages of gamma rays irradiation used were $100 \mathrm{~Gy}, 200$ Gy, 300 Gy, and 400 Gy. Each dosage was tested to 500 grains with $11.8 \%$ water content. Mutation induction was done by a gamma rays irradiation of Irradiator Gamma Chamber 4000 A (sources $60 \mathrm{Co}$ ) instrument with 91.3786 krad/hour (913,786 Gy/hour).

The irradiated seeds of upland rice grains were referred as a first generation (M1) mutant. The M1 seeds were planted by one seed per planting holes technique. The distance between planting holes was $25 \mathrm{~cm}$ in the same line and $40 \mathrm{~cm}$ for interline. Seeds planting were carried out following standard operational procedure for upland rice cultivation.

Observations were done to several parameters such as plant high, the number of productive tillers, the length of panicle, harvest age, the number of empty grains, the number of full grain, the weight of 1000 grains, and grain number per tiller. Genetics variance of each M1 treatment was assessed by phenotype variance reduction of environment variant.

The calculation of superior lines was done by following selection limits value formula:
Correspondence: Ni Wayan Sri Suliartini, Faculty of Agriculture, Halu Oleo University, Kendari, Southeast Sulawesi, Indonesia.

Tel.: +62.401.3190105.

E-mail: sri.suliartini@gmail.com

Key words: Red rice; Gamma rays; Superior line; Southeast Sulawesi.

Acknowledgements: the authors would like to thank the Balai Penelitian Tanaman Pemanis dan Serat (Balittas).

Contributions: the authors contributed equally.

Conflict of interest: the authors declare no potential conflict of interest.

Received for publication: 17 February 2016.

Revision received: 12 May 2016.

Accepted for publication: 12 May 2016.

This work is licensed under a Creative Commons Attribution-NonCommercial 4.0 International License (CC BY-NC 4.0).

(C) Copyright N.W.S. Suliartini et al., 2016 Licensee PAGEPress srl, Italy

International Journal of Plant Biology 2016; 7:6475 doi:10.4081/pb.2016.6475

$$
\begin{gathered}
\mathrm{Xs}=\mathrm{X} . .+\mathrm{kp} \\
\sigma \mathrm{p}=\sigma 2 \mathrm{p} \\
\sigma 2 \mathrm{p}=\sum \mathrm{x} 2-\left(\sum \mathrm{x}\right) 2 \\
\mathrm{n} \\
\mathrm{n}-1
\end{gathered}
$$

where: X.., averages grains resulted from parental; k, 2.06 for intensity selection 5\%; p, phenotype standard deviation; $\sigma 2 p$, phenotypes variant; $n$, number of observed genotypes.

Based on this calculation, the selected lines was the lines with value $>$ Xs.

For harvest age and plant height, using the following formula:

$$
\mathrm{Xs}=\mathrm{X} . .-\mathrm{kp}
$$

The selected lines was the lines with value $<$ Xs.

\section{Results and Discussion}

\section{The estimations of Lethal Dosage 50}

Basically, $\mathrm{LD}_{50}$ aims to identify material sensitivity to mutagens. ${ }^{3}$ Based on the irradiation dosage correlation with percentage of surviving M1 Pae Loilo individual, it could be concluded that $\mathrm{LD}_{50}$ of Pae Loilo cultivars was about 360Gy (Figure 1A). Gamma rays irradia- 
tion causes seed injury and contributes to the negative impact of seeds to grows. ${ }^{4}$ The inhibition occurs due to free radical which resulted from gamma rays irradiation and this rays able to disturb and affect plants morphology, anatomy, biochemical, and physiological aspect and process. Previous research found such inhibition and destruction in black gram seeds. ${ }^{5}$

The relationship of irradiation dosage and percentage of survive Pae Pulu Pongasi individual was Quadratic Regression (Figure 1B):

$y=-0.0001 x 2-0.0779 x+99.663$ with $R 2=0.9643$

Based on the calculation, $\mathrm{LD}_{50}$ value founded was 416 Gy. Both cultivars had $\mathrm{LD}_{50}$ more than 300 Gy. Pae Pulu Pongasi cultivar had $\mathrm{LD}_{50}$ for 416 Gy and Pae Loilo cultivars has 360 Gy. These data showed that both cultivars had different sensitivity to Gamma rays irradiation. Pae Loilo cultivar had higher sensitivity to Gamma rays irradiation compared to Pae Pulu Pongasi cultivars. Based on $\mathrm{LD}_{50}$ value of Pae Loilo cultivars $\left(\mathrm{LD}_{50}=360\right.$ Gy) and Pae Pulu Pongasi cultivar $\left(\mathrm{LD}_{50}=416 \mathrm{~Gy}\right), 400 \mathrm{~Gy}$ was the highest dosages allowed for gamma irradiation. In 500 Gy treatment, no seed was able to grow.

\section{Selection of superior lines of M1 population}

Basic population with high genetic diversity provides great opportunities to get a variety of targeted characters. Genetic diversity of Pae Pulu Pongasi first generation showed the tendency to increase along with Gamma rays irradiation until 300 Gy. At 400 Gy, a decrease was founded in genetic diversity. These findings similar with the research in Sorghum where the highest genetic diversity found at 100-300 Gy treatment. ${ }^{6}$
Gamma rays irradiation has the ability to changes nucleotides bases in DNA as well as in chromosomes. High dosage (400 Gy in Pae Pulu Pongasi cultivars) caused great changes of plant genetic composition. Irradiation contributes to genes structure such as translocations, inversions, duplications, deficiencies/ deletion. ${ }^{7}$ Deletion in essential genes or changes of genes cause inhibition of plant grows and plant productivity. Deleted genes as a result of deletion process can occur in chromosomes and able to cause mortality or decrease of plant viability. There was 36 individual of Pae Pulu Pongasi first generation which able to survive and reproduce after irradiation with 400 Gy.

Chlorophyll content and grain dry weight characters of M1 Pae Pulu Pongasi after 400 Gy exposure were zero. A zero value means that genetic diversity of population similar with parental control. As the result, characters improvement through selection was ineffective. Genetic diversity decrease was not founded at 400 Gy treatment in most of Pae Loilo first generation, except chlorophyll content, the number of full grain, the number of empty grain, percentage of empty grain and grain dry weight (Table 1). Genetic diversity decrease was affected by a different number of survive and productive individual. A number of survive and productive individual of Pae Loilo first generation at 400 Gy were 58 individual.

Four cultivars, M1.156K2D3, M1.190K2D3, M1.192K2D3, and M1.222K2D3 were selected from Pae Pulu Pongasi first generation population (Table 2). These cultivars resulted from a population with 300 Gy irradiation treatment. M1.156K2D3, M1.192K2D3, and M1.222K2D3 had short harvest age, ranging from 8 to 10 days compared to parental. But the yield grains were low compared to parental. Therefore, these cultivars had a low potential for further superior line development. However, the cultivars had it's potential for further development for age's characteristics. These individuals had short harvest age compared to other cultivars.

Based on selected criteria, three cultivars were selected from the first generation of Pae Pulu Pongasi population. Compared to parental, three cultivars had short harvest age (about 10 to 11 days) and grains weight about $43.08 \mathrm{~g} /$ clumps to $58.87 \mathrm{~g} /$ clumps (Table 2). Faster harvest age was caused by the ability of individual to complete vegetative phase grows shortly. The first selected generation of Pae Pulu Pongasi, based on harvest age and grains productivity was supported by a number of productive tillers, the length of panicle, except for $\mathrm{M} 1.27 \mathrm{~K} 2 \mathrm{D} 1$, and had fuller grain, a grain with higher starch content compared to control. Theoretically, increased number of productive tiller lead to increased number of grains panicle. Grains should be filled by starch through photosynthesis process which effective to produce photosynthate in high rate. ${ }^{8}$ The number of full grains per panicle has positive correlation with rice grains production. ${ }^{9}$ Grains number per clump of rice have a positive correlation with panicle length, plant's height and a number of the productive tillers. ${ }^{10}$ Moreover, M1.81K2D1 had the potential to develop as superior line candidates for lodging resistance. M1.81K2D1 had $103 \mathrm{~cm}$ in height and classified as a plant with the moderate stem. Rice plant with high stem category has $120 \mathrm{~cm}$ in height.

The increased amount of grain yield from 3 selected cultivars ranging from 40 to $55 \%$ compared to control (Table 3). Three cultivars of Pae Loilo first generation from 684 individual at 4 different population treatment were selected by their harvest age and grain productivity ability. Based on harvest age below the average of population minus selection intensi-

Table 1. Genetic diversity profiles of Pae Loilo first generation morphological and anatomical characters.

\begin{tabular}{lcccccccccccc} 
Gamma rays irradiation dosage & CC & PH & HA & PT & LP & FG & EG & PEG & WDG & WG \\
100Gy & 0.02 & 272.13 & 13.55 & 27.96 & 4.36 & 583.84 & 301.02 & 165.43 & 862.85 & 0.010 \\
200Gy & 0.36 & 143.50 & 14.31 & 32.23 & 7.78 & 1752.63 & 2139.71 & 788.13 & 52.71 & 0.007 \\
\hline 300Gy & 2.58 & 258.29 & 29.88 & 49.47 & 6.33 & 3477.44 & 3526.83 & 1359.90 & 1150.13 & 0.007 \\
400Gy & 1.04 & 324.78 & 36.36 & 74.67 & 9.41 & 1308.86 & 2104.41 & 502.69 & 8.55 & 0.042 \\
\hline
\end{tabular}

CC: Chlorophyll content, PH: Plant height, HA: Harvest age (dap=days after planting), PT: Number of productive tillers, LP: length of panicle, FG: Full grain, EG: number of empty grains, PEG: Percentage of empty grain, WG = weight of dry grains, WG: Weigh of 100 rice grains.

Table 2. Observed character profiles of selected Pae Pulu Pongasi first generation cultivars.

\begin{tabular}{lccccccc} 
Rice lines & PH $(\mathrm{cm})$ & HA (dap) & PT (tillers) & LP (cm) & FG (grain) & EG (grains) & WG (g) \\
M1.27K2D1 & 174 & 141 & 39 & 28.3 & 229 & 5 & 2.80 \\
M1.81K2D1 & 103 & 141 & 51 & 32.0 & 248 & 2.64 \\
\hline M1.190K2D3 & 183 & 140 & 33 & 33.3 & 226 & 20 & 2.94 \\
Parental control & 164.26 & 150.04 & 29.40 & 30.16 & 223.38 & 14.50 \\
\hline
\end{tabular}

PH: Plant height, HA: Harvest age (dap=days after planting), PT: Number of productive tillers, LP: length of panicle, FG: Full grain, EG: number of empty grains, WG: Weigh of 100 rice grains. 
ty Constanta 5\%, multiplied by population standard deviation ( $\mathrm{x}-2.06 \mathrm{SD})$ and grains productivity beyond the average of population plus selection intensity Constanta 5\%, multiplied by population standard deviation $(\mathrm{x}+2.06 \mathrm{SD})$ were M1.11K3D2, M1.126K3D2, and M1.168K3D3. M1.11K3D2 had grain productivity under the average of control and considered not potential to further development as superior lines, especially in grain productivity characters.

The selection based on harvest age parameters under parental control average minus selection intensity Constanta 5\% and multiplied by parental control standard deviation ( $\mathrm{x}$ -2.06 SD) (142.19 dap) and grain productivity beyond parental control plus selection intensity Constanta $5 \%$ and multiplied by parental control standard deviation ( $\mathrm{x}+2.06 \mathrm{SD})$ (147.72 g/clump), 7 selected M1 cultivars of Pae Loilo were founded. This seven individual had shorter harvest age than 134.68 dap and grains number reached above $130.47 \mathrm{~g} /$ clump. All of the cultivars founded in Pae Loilo first generation were treated at $100 \mathrm{~Gy}$. In all of the tested dosage, 100 Gy seems to be the optimum dosage for Pae Loilo cultivars to generate superior lines candidates. Gamma rays irradiations dosage is important to induce genetic diversity which leads to positive impact to plant. ${ }^{4}$ Generally, selected individuals had long panicle, but panicle length not significantly increase the number of grains, except M1.102K3D1. Increased of panicle length contributes to the weight of 100 grains parameter which founded in M1.6K3D1. In M1.6K3D1, panicles had longer size $(2.61 \mathrm{~cm})$ compared to parental control, but the number of grain per panicle (173 grains) decreased to 39.59 grains compared to the average result of control (212.59 grains). The increase occurred in weight of 100 grains, about $0.96 \mathrm{~g}$ compared to control. In this cultivar, photosynthate optimally used to fill the grain, not to increase the number of grains in a panicle. The increase of panicle will contribute to grain per panicle increase.

The high productivity of 7 cultivars was caused by a weight increase of 100 grains and larger size. As a consequence, the weight of 100 grains of rice cultivars had higher weight compared to the other rice grains parameter. The 100 grains of Inpago 7 superior lines had weight about $2.45 \mathrm{~g}$, while Inpago 1 and Inpago 3 had weight about $2.57 \mathrm{~g}$. The weight of 100 grains of Pae Pulu Pongasi was $2.80 \mathrm{~g}$ and Pae Loilo was $2.90 \mathrm{~g}$. Weight improvement of 100 grains of M1 Pae Loilo individuals was possible through gamma rays irradiation. This was showed by the weight of 100 grains of selected individual, about $3.23 \mathrm{~g}$ to $3.86 \mathrm{~g}$.

These individuals have the potential to develop as superior lines with high yield and short harvest age through plant genetic improvements programs. Individual with high grain productivity or short harvest age can be used as in the future programs of plant breeding as parental candidates to produce further superior lines. In such dosages, the increase rate reached about $49.61 \%$ to $62.67 \%$ compared to control. Grain yield productivity was decreased at 300 Gy treatment and the lowest productivity was founded at $200 \mathrm{~Gy}$. At $200 \mathrm{~Gy}$ irradiation dosage, plant productivity was $3.36 \%$.

\section{Conclusions}

The $\mathrm{LD}_{50}$ value of Pae Loilo cultivars and Pae Pulu Pongasi cultivar are 360Gy and416Gy, respectively. There are several individuals which have potentially for further superior lines development with medium harvest age and high productivity through further plant breeding, namely M1.27K2D1, M1.81K2D1 and M1.190K2D3 of Pae Pulu Pongasi cultivars the first generation resulted from Gamma rays irradiation using 100 and 300 Gy dosage, and
A

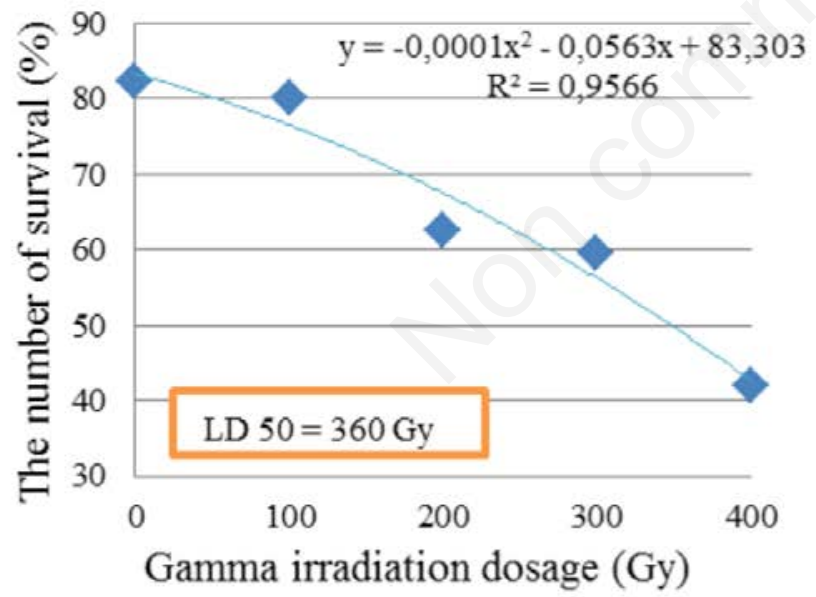

B

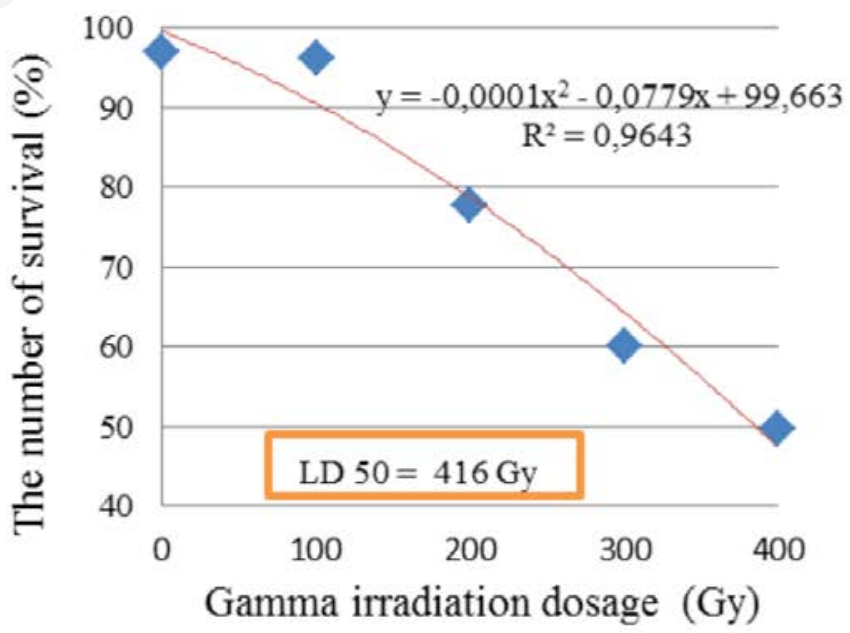

Figure 1. The relationship between gamma irradiation dosage and percentage of survive M1 Pae Loilo individual (A) and Pae Pulu Pongasi individual (B).

Table 3. Increased grains number of M1 Pae Pulu Pongasi cultivars.

\begin{tabular}{lcccc} 
Rice lines & $\begin{array}{c}\text { Grains rice weight of } \\
\text { selected individual (g/clumps) }\end{array}$ & $\begin{array}{c}\text { Grains rice weight of } \\
\text { parental control (g/clumps) }\end{array}$ & $\begin{array}{c}\text { Productivity gaps } \\
(\mathrm{g} / \mathrm{clump})\end{array}$ & $\begin{array}{c}\text { Increasing percentage } \\
(\%)\end{array}$ \\
M1.27K2D1 & 150.23 & 106.756 & 43.47 & 40.72 \\
M1.81K2D1 & 165.63 & 106.756 & 58.87 & 55.15 \\
\hline M1.190K2D3 & 149.84 & 106.756 & 43.08 & 40.36 \\
\hline
\end{tabular}


M1.6K3D1, M1.24K3D1, M1.37K3D1, M1.102K3D1, M1.104K3D1, M1.162K3D1, and M1.170K3D1 of Pae Loilo cultivars first generation resulted from Gamma rays irradiation using 100Gy, 200Gy dan 300Gy dosage. M1.81K2D1 is one of the potential individuals to develop as superior lines candidates with high grains result in productivity, medium harvest age, and has lodging resistance traits.

\section{References}

1. Suliartini NWS, Sadimantara GR, Wijayanto dan Muhidin T. Pengujian antosianin padi gogo beras merah hasil koleksi plasma nutfah Sulawesi Tenggara. Crop Agro 2011;4:43-8.

2. Gómez-Pando L, Eguiluz A, Jimenez J, et al. Barley (Hordeun vulgare) and kiwicha (Amaranthus caudatus) improvement by mutation induction in Peru. In: Shu QY (ed.) Induced plant mutations in the genomics era. Rome: Food and Agriculture Organization of the United Nations; 2009. pp 330-332.

3. Herison C, Rustikawati Sujono HS, dan Syarifah IA. Induksi Mutasi melalui sinar gamma terhadap benih untuk meningkatkan keragaman populasi dasar jagung (Zea mays L.). Akta Agrosia 2008;11:57-62.

4. Tshilenge-Lukanda L, Kalonji-Mbuyi A, Nkongolo KKC, Kizungu RV. Effect of gamma irradiation on morpho-agronomic characteristics of groundnut (Arachis hypogaea L.). Am J Plant Sci 2013;4:218692.

5. Devi SA, Mullainathan L. Effect of gamma rays and ethyl methane sulphonate (EMS) in M3 generation of blackgram (Vigna mungo L. Hepper). Afr J Biotechnol 2012;11:3548- 52 .
6. Surya MI, Hoeman DS. Evaluasi keragaman genetik sorgum manis pada mutan generasi Ke-2 hasil iradiasi gamma. Agrivita 2009;31:142-8.

7. BATAN. Kelompok Pemuliaan Tanaman. Available from: http://www.batan.go.id/ patir/_pert/pemuliaan/pemuliaan.html. Accessed on: 13 October 2012.

8. Wangiyana W, Laiwan Dan Sanisah Z. Pertumbuhan dan hasil tanaman padi var. ciherang dengan teknik budidaya SRI (System of Rice Intensification) pada berbagai umur dan jumlah bibit per lubang tanam. Crop Agro 2009;2:70-8.

9. Ishak. Agronomic traits, heritability and G $\mathrm{x} E$ interaction of upland rice (Oryza sativa L.) Mutant Lines. J Agron Indonesia 2012;40:105-11.

10. Khan AS, Imran M, Ashfaq M. Estimation of genetic variability and correlation for grain yield component in rice (Oryza sativa L.). J Agric Environ Sci 2009;6:585-90. 